\title{
CHEMICAL TECHNOLOGIES AND ENGINEERING
}

DOI https://doi.org/10.30525/978-9934-26-109-1-13

\section{ХІМІЧНІ ТЕХНОЛОГІЇ ТА ІНЖЕНЕРІЯ ЧУТЛИВИЙ ДАТЧИК ДЛЯ ПОТЕНЦІОМЕТРИЧНОГО ВИЗНАЧЕННЯ АНІОНІВ НА ОСНОВІ ВПЕ МОДИФІКОВАНОГО ЧЕТВЕРТИННОЮ АМОНІЙНОЮ СІЛЛЮ}

\author{
Смик Н. I. \\ кандидат хімічних наук, дочент, \\ доиент кафедри аналітичної хімії \\ Київський національний університет імені Тараса Шевченка
}

\section{Самплавський В. В.} студент

Київський національний університет імені Тараса Шевченка м. Київ, Україна

Унікальні властивості модифікованих вугільно-пастових електродів (МВПЕ) - простота виготовлення матеріалу із заданими властивостями, легкість оновлення поверхні, можливість застосування в потоці, широка область робочих потенціалів, низький фоновий струм та екологічна безпечність - в останні роки забезпечили їх широке застосування як перетворювачів біохімічного відгуку в біосенсорах, чутливих елементів детекторів в високоефективній хроматографії, капілярному зонному електрофорезі, проточноінжекційному аналізі та робочих електродів в вольтамперометрії. Так, в інверсійній вольтамперометрії (IBA) застосування МВПЕ дозволяє значно покращити селективність та чутливість визначення завдяки попередньому вибірковому виділенню досліджуваної речовини із складної суміші та іiі концентрування на поверхні робочого електроду [1]. Ряд прикладів застосування подібних електродів для визначення катіонів та аніонів, запропонованих в літературі, показали їх придатність як потенціометричних датчиків [2].

Нітрат в водних системах необхідний для зростання водоростей і фітопланктону, але занадто швидке збільшення їх маси, що 56 
стимулюється надмірним вмістом нітрат-йонів, призводить до евтрофікації і подальшої загибелі тварин. Ці проблеми визнані в усьому світі, для їх подолання відповідними міжнародними та урядовими організаціями, до складу яких входять усі промислово розвинені країни, були обгрунтовані норми вмісту нітратів й розроблені програми для контролю їх вмісту в об’єктах навколишнього середовища та в продуктах харчування. Отже, необхідність і важливість створення чутливих, вибіркових та економічних методів контролю вмісту нітратів в об'єктах різної природи беззаперечна.

Найбільш чутливі та вибіркові методи визначення вмісту $\mathrm{NO}_{3}{ }^{-}$ іонна хроматографія (IX) та капілярний зонний електрофорез складні в реалізації, дороговартісні, потребують високої фахової підготовки персоналу та складної пробопідготовки (IX), тому не можуть бути застосовані на місці відбору проб. Більш прості та широко вживані методи - фотометричний та люмінесцентний - дозволяють 3 достатньою чутливістю визначати вміст $\mathrm{NO}_{2}^{-}$(після переведення в азобарвник за реакцією азосполучення 3 ароматичним аміном), визначення $\mathrm{NO}_{3}^{-}$можливе лише після відновлення до нітриту. Ці методи потребують довгої пробопідготовки i не можуть бути застосовані для аналізу на місці відбору проб. Результати застосування ряду спеціальних тест-систем, що випускаються промисловістю, не завжди задовольняють вимоги за чутливістю та вибірковістю при застосуванні у морській воді високої солоності. Пряма потенціометрія із застосуванням іонселективних електродів (ICE) вибіркових до $\mathrm{NO}_{3}^{-}$видається перспективним методом для роз`в'язання поставленої задачі.

В представленій роботі як чутливий датчик для потенціометричного визначення нітрат-йонів запропоновано вугільнопастовий електрод модифікований тетрадециамоній нітратом (ЧАС). В роботі оптимізовано спосіб отримання МВПЕ й детально досліджені його властивості. Область лінійності $\left(1 \cdot 10^{-5}-1 \cdot 10^{-1}\right.$ моль/л) та нахил градуювального графіку (61 мB/pC $\left.\mathrm{NO}_{\mathrm{NO}}\right)$, селективність (табл. 1) й час відгуку (не перевищує 30 с), стабільність аналітичного сигналу в широкій області рН $(3,2$ - 9,4) й іонної сили дозволили застосувати розроблений електрод для визначення вмісту $\mathrm{NO}_{3}{ }^{-}$у водах 3 високою солоністю й в овочах.

Попередньо було встановлено оптимальні умови визначення $\mathrm{NO}_{3}^{-}$ у розчинах: $\mathrm{pH} 5 \pm 1$ та $\mathrm{C}\left(\mathrm{Na}_{2} \mathrm{SO}_{4}\right)=1 \cdot 10^{-3}$ моль/л для контролю іоннної сили розчину). 
Таблиця 1

Потенціометричні коефіціснти селективності МВПЕ

\begin{tabular}{|c|c|}
\hline $\mathbf{X}$ & $\mathrm{k}_{\mathrm{NO} 3 / \mathrm{x}}{ }^{\mathrm{n}}{ }^{10 \mathrm{~T}} \cdot 10^{-2}$ \\
\hline Ask $^{-}$ & \multirow{2}{*}{$4,0 \cdot 10^{-2}$} \\
\hline $\mathrm{Cit}^{-}$ & \\
\hline $\mathrm{NO}_{2}^{-}$ & $1,3 \cdot 10^{-2}$ \\
\hline $\mathrm{SO}_{4}{ }^{2-}$ & $3,2 \cdot 10^{-3}$ \\
\hline $\mathrm{I}^{-}$ & $6,3 \cdot 10^{-2}$ \\
\hline $\mathrm{HPO}_{4}{ }^{2-}$ & $1,1 \cdot 10^{-5}$ \\
\hline $\mathrm{Cl}^{-}$ & $1,0 \cdot 10^{-4}$ \\
\hline
\end{tabular}

Розроблені методики були апробовані при аналізі розчинів, що за складом імітують морську воду, розчинів природної морської солі та води 3 морського океанаріуму «Морська казка», Киів. Також, за допомогою запропонованого МВПЕ було визначено вміст нітратйонів у овочах (рукола, укроп, салат та ін.). Експериментальні значення було перевірено методом «введено-знайдено». Отримані результати свідчать про задовільну чутливість, правильність та відтворюваність.

\section{Література:}

1. О.А. Запорожець, Н.І. Смик, Н.О. Туманік, Є.В. Заболотній, А.В. Заскальна Модифікований вугільно-пастовий електрод як чутливий датчик для вольтамперометричного визначення токсикантів. Київська конференція з аналітичної хімії: Сучасні тенденції. (Київ, 2018). Київ, 2018. С. 82.

2. J. Schwarz, K. Trommer and M. Mertig. Solid-Contact Ion-Selective Electrodes Based on Graphite Paste for Potentiometric Nitrate and Ammonium Determinations. American Journal of Analytical Chemistry. 2018. № 9. P. 591-601. 